Article \# 1

\title{
In search for effective treatment for human diseases, should researchers be permitted to use embryonic stem cells within their research programs?
}

\author{
James J. Rusthoven, MD. MHSC
}

The destruction of human embryos for research purposes has continued to trouble members of both religious faith and secular communities within our society. Research is moving quickly toward developing new cellular therapies using alternative sources of stem cells such as adult stem cells ${ }^{1}$ or induced pluripotent stem cells. ${ }^{2}$ However, some scientists continue to harvest embryonic stem cells on the assumption that their pluripotent status makes them the best source of therapies for the widest spectrum of diseases. With the large and growing number of extra embryos from in vitro fertilization, they are also in greater supply and possibly less costly to process and propagate than relatively rare adult stem cells. Similarly, induced pluripotent stem cells require carefully orchestrated laboratory conditions to produce them from somatic cells and they are still being characterized as to their multidimensional similarity to embryonic stems cells.

A full range of moral arguments against the destruction of human embryos for research cannot be covered in this short piece. I will touch on three issues that must be addressed to engage in a morally robust dialogue for or against their destruction for research purposes: 1) Is there scientific evidence that destroying human embryos is the only way to develop cell-based therapies for human beings with serious diseases? 2) Is there moral justification to destroy human embryos in the hope that experimenting with their stem cells will result in effective therapies for post-birth human beings with severe diseases? 3) Can we justify resisting the destruction of human embryos for research based on their moral value as human beings?

As already mentioned, alternative sources of stem cells are available and work has moved quickly in the development of therapies using adult stem cells, often but not always as tissue- or organ-specific treatments. Early clinical studies have been reported and are ongoing showing the ability of adult stem cells to replace damaged or geneticallydysfunctional tissues. The first human clinical trial of human embryonic stem cell-derived neurogenic tissue has begun but the Food and Drug Administration remains vigilant over the known risk of tumour formation by embryonic stem cells. $^{3}$ Thus, embryonic stem cells are not the only real or potential source of therapies and there are no scientific grounds to assume that they will produce the best therapies, with greater efficacy and less risk of causing harm than those produced by other stem cells. History has shown that logical scientific intuition and planning does not always lead to the most important and useful scientific discoveries, as seen in serendipitous observations such as the discovery of the bacteriocidal properties of Penicillium mold.

Moral assessments of the human embryo have sometimes been based on utilitarian appeals that the development of therapies to relieve suffering of post-birth human beings should override the protection of embryos. Some have argued that embryos should be treated with respect, despite killing them for research that may help others later. ${ }^{4,5}$ However, such efforts to salvage some moral value ring hallow to the point of absurdity if sacrificing unique human individuals somehow represents respect. ${ }^{6,7}$ There are no statements from authoritative sacred texts that clearly spell out the moral status of the embryo. ${ }^{8}$ Arbitrary developmental cutoffs for lesser or greater moral status, such as complete organ formation, have been proposed since Pythagorus ${ }^{9}$ and Aristotle ${ }^{10,11}$ and are found in some Christian, Jewish, and Muslim traditions ${ }^{12}$ but cannot be justified on rational or religious grounds.

Despite this lack of explicit clarity, traditional Jewish and Christian concepts of human value have drawn from their written scriptures as authoritative evidence that human beings are uniquely valuable as image-bearers of God. This inherent, ontic value has been interpreted by some scholars to impart full inherent human value throughout human development. ${ }^{13}$ In addition, Christianity brought into the surrounding pagan world a large-scale change in attitudes toward the value of the human beings, particularly those most vulnerable in society. ${ }^{14}$ If considered as some of the most vulnerable and needy members of our kind, embryos require surrogate providers and decision-makers who act in their best interest as they develop toward full functional membership, just as surrogates are expected to support designated incapacitated persons. This relational dependency throughout development has greater moral justifiability than 
arbitrarily choosing biological developmental milestones on which variable moral significance can be attached through attempts at rational consensus alone.

Secular arguments have also cast doubt on the moral justifiability of destroying embryos for research. After an elegant repudiation of the moral convincibility of arguments both for and against destroying embryos for research, Don Marquis concludes that failing to respect the basic interests of human beings for research purposes is wrong, that age discrimination is wrong, and that all of us were once embryos and therefore destruction of human embryos for research is wrong. While it seems admittedly counterintuitive to give embryos the same moral respect as adults, he confesses that his intuitions carry no greater moral force and authority than anyone else. He concludes that the failure of arguments in favour of the moral permissibility of embryo destruction for research suggests that it is not permissible. ${ }^{15}$ This would be analogous to the precautionary principle in environmental ethics wherein new technologies that might be harmful to the environment should be not not be applied until sufficient investigation of their short- and long-term impact is carried out and their safety demonstrated.

In my view, embryos are unique human beings which, placed in the proper nutritive and nurturing environment, will likely develop into unique post-birth human beings with maturing capacities to function as independent human beings. Human society should assume moral responsibility for its most vulnerable and needy during all stages of human development before and after birth. One can claim moral authority in common human opinion, intuition, or from transcendent authority beyond human authority. In a pluralistic society, I would not argue primarily for a legal ban on the destruction of human embryos for research. I would argue that funding sources and scientists be persuaded to abstain from supporting the killing of human embryos for research and to divert their resources to other sources of stem cells and methods of cell-based therapies. One might argue that the moral health of a society is reflected in how it treats the most vulnerable and needy of its members, including the unborn.

\footnotetext{
REFERENCES

${ }^{1}$ Meyer GP, Wollert KC, Lotz J, et al. Intracoronary bone marrow cell transfer after myocardial infarction: eighteen months' follow-up data from the randomized, controlled BOOST (Bone marrOw transfer to enhance ST-elevation infarct regeneration) trial. Circulation 2006;113:1287-94.

${ }^{2}$ Moretti A, Bellin M, Welling A, et al. Patient-specific induced pluripotent stem-cell models for long-QT syndrome. N Engl J Med 2010;363:1397-1409.

${ }^{3}$ Stein, R. First Patient Treated in Stem Cell Study. Washington Post (October 11), 2010. http://www.washingtonpost.com/wpdyn/content/article/2010/10/11/AR2010101102946.html?sid=ST2010101102993 (accessed December 27, 2010).

${ }^{4}$ Meyer, M. J. and Nelson, L. J. Respecting What We Destroy: Reflections on Human Embryo Research. Hastings Center Report 2001; $31(1)$ : 18 -22 .

${ }^{5}$ Lebaczq, K. On the Elusive Nature of Respect. In Holland, S., Lebacqz, K., and Zoloth, L. The Human Embryonic Stem Cell Debate. Cambridge, MA: The MIT Press, 2001, 158-161.

${ }^{6}$ Baylis, F. Human Embryonic Stem Cell Research: Comments on the NBAC Report. In Holland, S., Lebacqz, K., and Zoloth, L. The Human Embryonic Stem Cell Debate. Cambridge, MA: The MIT Press, 2001, 53, 54.

${ }^{7}$ Callahan, D. The Puzzle of Profound Respect. Hastings Center Report 1995; 25(1): 39-40.

${ }^{8}$ Marquis, D. Stem Cell Research: The Failure of Bioethics. In The Stem Cell Controversy: Debating the Issues, $2^{\text {nd }}$ ed., Ruse, M. and Pynes, C.

A., eds. New York: Prometheus Books; 2006, 188; O’Donovan, O. Begotten or Made? Oxford: Oxford University Press; $1984,65$.

${ }^{9}$ Carrick, P. Medical Ethics in the Ancient World. Washington, D. C.: Georgetown University Press; 2001, $126,127$.

${ }^{10}$ Jones, D. A. The Soul and the Embryo. New York: Continuum; 2004, 22-32.

${ }^{11}$ Zoloth, L. The Ethics of the Eighth Day: Jewish Bioethics and Research on Human Embryonic Stem Cells. In Holland, S. Lebacqz, K., and

Zoloth, L. The Human Embryonic Stem Cell Debate. Cambridge, MA: The MIT Press; 2001, 98-100.

${ }^{12}$ Novak, D. The Sanctity of Human Life. Washington, D. C.: Georgetown University Press; 2007, 50-58.

${ }^{13}$ Ibid, 68.

${ }^{14}$ Ferngren, G. B. Medicine \& Health Care in Early Christianity. Baltimore: The Johns Hopkins University Press; 2009, 97-104.

${ }^{15}$ Marquis, op.cit., 196, 197.
}

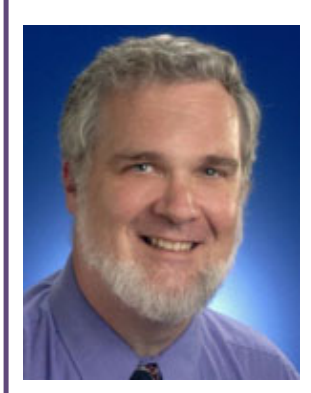

Author Profile

Jim Rusthoven is a medical oncologist by training, and currently serves as a professor in the department of oncology at McMaster University. He completed his medical training at the University of Illinois, later going on to pursue a MHSc degree in biomedical ethics at the Joint Centre for Bioethics, University of Toronto. He is currently completing a doctoral dissertation on the ethics of stem cell research at Trinity College, University of Bristol in the United Kingdom. 


\section{ESCs: The unused IVF embryo problem}

The field of embryonic stem cell (ESC) research faces challenges from the moral front as well as the scientific and practical front. Dr. Rusthoven contests the use of ESCs by questioning the morality in destroying human embryos for the sake of medicine, while showing support for the use of adult stem cells as a viable alternative for cell-based therapies. While Dr. Rusthoven makes a compelling case on moral grounds, his points do not address the following argument: Embryos slated for destruction, as in the case of supernumerary embryos produced for in-vitro fertilization (IVF), can be used for science rather than wasted.

According to Canadian law, embryos can only be produced for assisted reproduction therapies.i Donors have the option of cryo-preserving their surpluses, destroying them, or releasing them for research. The issue of donating embryos for research brings a set of ethical and policy issues which cannot be covered within the confines of this response. In any case, the point is that these embryos are available for research. While the number of embryos available for ESC research is not documented, donation to research is indeed a significant option for IVF users. ii So, if this source is available for researchers, is science faced with a moral issue in using these embryos?

One can argue that other couples or individuals who want children can adopt these surplus embryos and therefore there isn't a need to destroy them or donate them to research. I would argue that the surplus embryos would outnumber the couples looking to adopt and we are still faced with the question of what to do with the remaining. Moreover, studies have shown that couples are more likely to either donate their surplus embryos to science or destroy them, rather than give them up for adoption.iii, iv So, adoption does not seem to be a feasible solution.

In my view, the destruction of a human embryo is morally wrong. However, this is my opinion based on my own morals and I do not wish to force this on others. Present Canadian law does not prevent patients from donating their surplus embryos to science nor does it prevent a patient from discarding these embryos. Given the circumstances then, I would rather have ESC researchers use the donated embryos to help advance medicine rather than have them discarded, which is wasteful.

i Nelson, E., et al. Informed consent to donate embryos for research purposes. $J$ Obstet Gynaecol Can 30, 824-836 (2008). ii Cohen, C.B. Ethical and policy issues surrounding the donation of cryopreserved and fresh embryos for human embryonic stem cell research.

Stem Cell Rev 5, 116-122 (2009).

iii Lanzendorf, S., Ratts, V., Keller, S. \& Odem, R. Disposition of cryopreserved embryos by infertility patients desiring to discontinue storage. Fertil Steril 93, 486-489.

iv Hammarberg, K. \& Tinney, L. Deciding the fate of supernumerary frozen embryos: a survey of couples' decisions and the factors influencing their choice. Fertil Steril 86, 86-91 (2006).

C. Geeth Gunawardana, Ph.D. is a researcher at the University of Toronto.

\section{On the premature declaration of ESCR's demise}

The moral implications of using human embryonic stem cells for the purposes of scientific research are carefully outlined in Rusthoven's article entitled 'In the search for effective treatments for human diseases, should researchers be permitted to use embryonic stem cells within their research programs?'. Throughout the article, Rusthoven provides both evidence- and opinion-based statements to argue that the ethical barriers of using embryonic stem cells cannot be ignored, and that resources should instead be streamlined towards other forms of stem cells. While the ethical arguments presented are quite sound, a number of points require clarification.

Rusthoven states that there are 'no scientific grounds' to assume that embryonic stem cells will result in the best therapies, but this is not a fair statement. A search of the largest clinical trials registry in the United States (clinicaltrials.gov) only identifies 11 registered trials involving embryonic stem cells and human subjects, compared to the thousands of trials involving other sources of stem cells. Given the lack of clinical research involving embryonic stem cells (the first trial was only approved by the FDA in 2009), it is not possible to compare or fully ascertain the therapeutic potential of these cell types.

Moreover, embryonic stem cells continue to be investigated in the realm of scientific research, which is a testament to the therapeutic potential assigned by experts in the field. Whether or not this potential exceeds that of adult stem cells has yet to be determined, but restricting embryonic stem cell-based research will only add to the mystery, not the solution. If research in this area is halted, might the scientific community be burning bridges given that the therapeutic potential (if any) of embryonic stem cells has yet to be fully understood?

Another point of contention worth mentioning is Rusthoven's stance on abortions in the context of this discussion, which is currently not mentioned. If the moral permissibility of embryos is to be questioned, does this argument apply to abortions as well? Or is it only limited to research practices?

Finally, Rusthoven concludes by acknowledging the pluralistic construct of society and does not advocate for a legal ban against destroying embryos, all while advocating for a shift in focus towards alternative stem cell sources. If a legal ban is not implemented, what possible measures can be taken to ensure that progress in embryonic stem cells research is halted?

Wilson Kwong is a MSc candidate studying at the University of Toronto. 


\section{Response to Comments - Article \#1}

I would like to thank Dr Gunawardana and Mr Kwong for their thoughtful responses to my stated position on the use of human embryonic stem cells for research purposes. I will address the responses of each in sequence, then provide final closing comments.

Dr Gunawardana notes quite rightly that I do not address the question of the use of leftover embryos after attempts at in vitro fertilization. I chose rather to devote the limited space allowed to probe the fundamental moral justifications of preserving human embryos rather than destroying them. Dr Gunawardana states that, in his view, it is morally wrong to destroy human embryos but that this is a private moral view that should not be imposed on others. My argument that I would not primarily argue for a legal ban means that I would primarily present the argument against their destruction on moral grounds. In a pluralistic society, I would present my moral case, just as others might to justify their destruction, with the hope that an increasing proportion of society would be persuaded not to destroy human embryos. I would similarly try to show scientists that their choices to engage in research that destroys human embryos are moral choices, not neutral ones about which only others need to be morally concerned.

Dr Gunawandana takes a somewhat utilitarian approach to his moral objection to the destruction of human embryos in suggesting that the reality of leftover embryos IVF forces one to default to the position that they be destroyed for research. While his personal objection to embryo destruction causes him to favour embryo adoption, he feels that the realities of demand and preference would still leave leftover embryos even if embryo adoption becomes more popular. He then seems morally pinned to the wall, forced to support destroying embryos for research purposes over discarding them altogether. Based on the arguments that I put forward, I would ask: if one really feels that destroying human embryos is morally wrong, why accept IVF as a morally viable method of overcoming infertility as long as leftover embryos is a common consequence? Would it not be taking the moral high road to encourage adopting infants or children left orphaned by losing both parents to disease, war, etc. rather than become confronted with the dilemma of extra embryos as a byproduct of an imperfect technology like IVF? This is imperfect technology based largely on the morbidity of hormonal manipulation and the inability to efficiently fertilizing one embryo at a time in vitro, then implanting one at a time in utero. With the likely need for repeated attempts before successful implantation, the costs are prohibitive for most couples and any moral concerns about dealing with extra embryos are overridden by this financial reality.

Mr Kwong feels that my statement that there are no scientific grounds to assume the superiority of embryonic stem cells as the eventual source of the best therapeutic products of stem cell research is not a fair statement. Though I understand his rebuttal, I stand by my statement. In my judgment, considerable uncertainties around the tumourogenic potential and biological stability of differentiated cell products of embryonic stem cells versus adult stem cells are a major concern. This does not give me confidence that embryonic stem cells will have a better chance of creating stable, safe, biological therapies, even if the moral concerns are not considered. Rather, I think the reasons for favouring embryonic stem cells are often of a more practical nature, such as relative ease of access and less cost.

Of greater concern to me is the way the arguments usually go. That is, rather than taking a moral stance and then determining a direction of scientific study that follows that moral stance, the direction of the scientific pursuit is often chosen and driven by innate curiosity, funding practicalities, career decisions, etc. Only later are the moral implications addressed. In my view, this is a symptom of a larger societal priority for finding solutions to human problems through science at the expense of moral consequences rather than routinely incorporating moral consciences and implications carefully into choices of scientific research direction. Mr Kwong concludes by questioning what possible other measures could be taken to ensure that the killing of human embryos for research would be halted. My answer is that legal banning will not improve the moral position of a society. At best it will satisfy the contention of a minority that legal restriction will lead to improvements in moral attitudes. I think history shows that legal prohibitions do not change morality; they generate black markets.

I might not object to a legal ban. However, in a democratic and pluralistic society I would rather advocate for persuading others that destroying human embryos for research purposes is not the direction to go. Science has resulted in amazing and helpful discoveries but also has a history of major discoveries based on serendipitous observations or counterintuitive results. I actually have considerable faith in the versatility science, in its ability to circumvent obstacles to what appears at first glance to be the best or only way to move forward. I think we are morally stronger as a society if we value ourselves as human beings similarly at all stages of development and at all levels of cognitive and physical capacity. If those less developed or capable are considered equally deserving of nurturing and protection by those who are more fully developed and capable, I think it would be morally better to choose other sources of human stems cells for research on new therapies. Given what we have already seen with induced pluripotent stem cell research, I feel that such research directions will bear worthy therapeutic fruit if the science is done well. 